\title{
Polysèmes
}

Revue d'études intertextuelles et intermédiales

\section{Photography and Trauma: An Introduction}

\section{Laurence Petit and Aimee Pozorski}

\section{(2) OpenEdition}

\section{Journals}

Electronic version

URL: http://journals.openedition.org/polysemes/3366

DOI: 10.4000/polysemes.3366

ISSN: 2496-4212

\section{Publisher}

SAIT

\section{Electronic reference}

Laurence Petit and Aimee Pozorski, «Photography and Trauma: An Introduction », Polysèmes [Online], 19 | 2018, Online since 30 June 2018, connection on 23 September 2020. URL : http:// journals.openedition.org/polysemes/3366; DOI : https://doi.org/10.4000/polysemes.3366

This text was automatically generated on 23 September 2020

Polysèmes 


\title{
Photography and Trauma: An Introduction
}

\author{
Laurence Petit and Aimee Pozorski
}

His mother wrapped him up in a shawl and gave him a passport photograph of herself as a student. She told him to turn to the picture whenever he felt the need to do so. His parents both promised him that they would come and find him and bring him home after the war.

(Dori Laub 1992)

\section{Survival, testimony, and witness}

1 The 1992 coauthored collection Testimony by Shoshana Felman and Dori Laub became a groundbreaking work in trauma studies largely due to its ability to situate trauma within a post-World War II context that, they argued, continued to struggle to bear witness to the atrocity of the Holocaust. Cognizant of the powerful courtroom testimonies of survivors of the Holocaust-the Nuremberg Trials (1945-1946) and the Eichmann Trial in Jerusalem (1961-1962) among the two most notable-Felman and Laub link such key terms as testimony, witness, ethics, justice, and history to a growing field of trauma studies after the war. Subtitled: Crises of Witnessing in Literature, Psychoanalysis, and History, the Testimony volume makes a powerful case for the humanities to acknowledge representations of the Holocaust and other traumatic events-in film, in poetry, in testimony, in the classroom, and in analysis-in order to bear witness to events in history where the court of law has generally failed.

2 In the third chapter in the collection, "An Event Without a Witness: Truth, Testimony, and Survival", Laub considers especially "the relation of witnessing to truth", particularly in the case of the Holocaust, and, in so doing, draws powerfully on his experience as the cofounder of the Fortunoff Video Archive for Holocaust Testimonies at Yale University (75). Laub notes his powerful and vexed position in relation to the 
project, signaling that he is simultaneously the cofounder of the Fortunoff archive, an interviewer on the project himself, a psychoanalyst who sees survivors, and a child survivor of the Holocaust. Within this powerful context, Laub describes the perfect example of another child survivor, whom he reveals only as Menachem S: a highranking officer in the Israeli army who spent a sabbatical year at Yale and was able to contribute to the Fortunoff archive.

3 A five-year-old child displaced to a labor camp near Krakow, Menachem heard his parents plotting his escape when he should have been asleep, and, when the opportunity arose, he was pushed out of the gate of the camp with only a shawl, a passport photograph, and a promise. He eventually found shelter in what Laub refers to as a "whorehouse"-"a marginal institution itself and therefore, more hospitable to the homeless"-and later with a gang of other boys who found refuge in homes and with families for short periods of time (86).

4 What is most interesting to Laub about this story is the status of the photograph during an incredibly traumatic time for the boy. As Laub suggests, when the boy was given an opportunity to pray by the gentile families who took him in, he prayed to the photograph of his mother. Laub writes:

What this young vagabond was doing with the photograph of his mother was, precisely, creating his first witness, and the creation of that witness was what enabled him to survive his years on the streets of Krakow. The story exemplifies the process whereby survival takes place through the creative act of establishing and maintaining an internal witness who substitutes for the lack of witnessing in real life. (87)

5 For Laub, survival and creativity become inextricable here, as the creativity allows for the boy to create a witness, and the witness in turn allows the boy to survive. The argument embodies the project at the heart of Testimony: a compelling claim that the ethical witness-either external or internal, real or imagined-is central for survivors of traumatic events.

6 For our purposes, however, the position of the photograph itself allows for another understanding of how text and image work together in the age of trauma. That the inspiration for Laub's key example is nothing more (nor less!) than a photograph suggests to us the unique place that photography holds in relation to narratives of trauma and witness. Laub continues with his focus on testimony in the story of Menachem when he suggests that the photograph provided an opportunity for the grown man to understand his testimony to his mother as a young boy, a testimony that "augment[ed] his ability to create a cohesive, integrated narrative of the event" (87). It allows him to come to understand in a coherent way the unspoken, unspeakable event central to his identity and his life.

7 For Laub, the story does not end there. As with any story that testifies to trauma in history-particularly from the anti-reparative psychoanalytic perspective that Laub contributes to the project-historic, institutionalized trauma brings tremendous costs. While Menachem ultimately reunites with his mother and father-discovering they had kept their promise after all-he does not see before him the vision of his young mother from the photograph and his father whom he knew as a five-year old, but rather "death camp survivors, haggard and emaciated, in striped uniforms, with teeth hanging loose in their gums" (88). Menachem is not able to speak to his mother and father as "Mom" and "Dad" but rather as "Mr. and Mrs." (88). "In regaining his real mother", Laub 
writes, "he inevitably loses the internal witness he had found in her image. This loss of his internal witness to whom he has addressed his daily prayers causes the boy to fall apart" (88). Again, the focus of this discussion is the image of the mother in the photograph, and the disconnect between the young mother Menachem carries with him to survive the war and the death camp survivor who returns to him in the form of a new reality. The man, Laub goes on to argue, becomes known for "repeated acts of bravery" in the Israeli army in order to "subdue the abandoned child victim within himself" (88). Ultimately, Laub argues:

as is evident in the example of this child survivor, the act of bearing witness at the same time makes and breaks a promise: the promise of the testimony as a realization of the truth. On the one hand, the process of the testimony does in fact hold out the promise of truth as the return of a sane, normal and connected world. On the other hand, because of its very commitment to truth, the testimony enforces at least a partial breach, failure and relinquishment of this promise. The mother who comes back not only fails to make the world safe for the little boy as she promised, but she comes back different, disfigured, and not identical to herself. She no longer looks like the mother in the picture. (91)

For Laub, the singular status of this case, of Menachem's survival, lies in the position of testimony: the way that testimony keeps a promise, and the simultaneous way it relinquishes it. The survival of Menachem's mother in some way paradoxically thwarts his testimonial progress. She comes back "disfigured," "haggard," and "emaciated" to make her own testimony to a murderous and irrational world.

The case also, however, highlights once again the status of the photograph, an artistic and creative artifact of a history of trauma. Throughout the collection, Felman and Laub provide stills from films, photographs of authors and intellectuals, yearbook images, paintings, and historical footage. In this essay, too, Laub makes careful use of the photograph, providing a photo of Menachem S and his mother in Krakow from 1940 (87), a photo of a very young Menachem from 1942 (89), and a photo of Dr. Menachem S from 1988 (90). Interestingly, we do not have access to the passport photo of Menachem's mother nor a photograph of Menachem's parents after the war. In all three cases, the photographs provided document Menachem's shifting gaze, from off in the future distance when with his mother in 1940, then suspiciously toward the photographer in 1942, to a leveling gaze in 1988, more than forty years after the war. Laub does not offer commentary on the photographs themselves nor their position in the essay, but their uninterpreted presence adds another layer to Laub's argument as well as to our discussions about testimony and trauma. Laub provides photographs in an essay ultimately about photographs, leaving unspoken the connection between photography and trauma we hope further to explore in this special issue.

\section{Theoretical encounters}

In addition to highlighting the status of photography in important debates surrounding trauma and testimony, we also seek to bring together theories of trauma with theories of the iconotext in an international context. A trauma theorist from the northeast U.S. and a text-image theorist from Western Europe, we seek within this issue to show the power of transcontinental and trans-theoretical research when discussing testimonial works. 
11 In the United States, such authors as Felman, Laub, Cathy Caruth, Dominick LaCapra, Ruth Leys, and, more recently, Rita Charon and Jennifer Yusin have been read predominately for articulating a theory of trauma that appeals to scholars of $20^{\text {th- }}$ and $21^{\text {st- }}$ century history. While Caruth's groundbreaking work, Unclaimed Experience: Trauma, Narrative, and History from 1996 takes the lead from Felman and Laub and closely reads such theorists as Paul de Man and Sigmund Freud in order to emphasize the traumatic nature of survival alongside the enigmatic nature of testimony itself, historian Dominick LaCapra seeks a more historicized method for articulating the impact of the Holocaust. Also advocating an historical approach that calls for cohesive answers to the problem of trauma, Leys continues LaCapra's project with her 2000 Trauma: A Genealogy, in which she argues that the "field of trauma studies today [...] continues to lack cohesion" (6); the work of Leys further worries about the future of trauma studies as much as a sense of a future history for survivors of trauma. More recently, Caruth's Literature in the Ashes of History (2013) sees, through a reading of child's language, "creative transformations" pointing the way to a "new language of psychoanalysis" and an interest in the status of the future that Jennifer Yusin, reading trauma theory in conversation with postcolonial thought, continues in her 2017 study, The Future Life of Trauma.

The convergence of postcolonial theory with trauma in the $21^{\text {st }}$ century context demonstrates the relevance that the emergence of this late $20^{\text {th }}$-century theory-one that grows out of the post-Holocaust moment-has for new discussions around such representations as political unrest, torture, the 9/11 terrorist attacks, and the status of slavery and Hiroshima in national and international discourses calling for reparations. In her 2006 monograph, Narrative Medicine: Honoring the Stories of Illness, Rita Charon draws on the ideas of trauma theory to underscore the significance of testimony in the lives of the terminally ill who are also seeking witnesses to their accounts of chronic illness and their confrontations with death.

13 Crossing the Atlantic Ocean, we see similar movements with regard to readings of literature from the trauma perspective. Marc Amfreville's 2009 Écrits en souffrance: Figures du trauma dans la littérature nord-américaine (Michel Houdiard) looks back to $19^{\text {th }}$ century American texts to see the often unarticulated, unexposed traumas depicted through the Gothic style of American Romanticism. Also understanding this connection between trauma and the $19^{\text {th }}$ century, Jean-Michel Ganteau and Susana Onega, editors of Trauma and Romance in Contemporary British Literature (London: Routledge, 2013), see trauma studies as a useful discourse in reading the romance genre in terms of contemporary British representations of trauma. Further, in going back to the key language of early trauma studies, Jean-Michel Ganteau and Susana Onega in Ethics and Trauma in Contemporary British Literature (Amsterdam: Rodopi, 2011) emphasize the "revival of interest in the ethical component of literature" that dates back to the 1980s -a component that we see specifically in conversations bringing together iconotextual language about photography with trauma studies in the $21^{\text {st }}$ century (7).

Ethics, testimony, and "exposure"-the polysemic term deliberately emphasized by Karen Jacobs in her special issue "Photography and Literature" (Jacobs 229)-are indeed at the heart of recent debates on photography and trauma in a postwar, post-Holocaust world defined as much by its "postmodern visual culture" as by its "contemporary trauma culture" (Luckhurst 2008, 3). Some critics even go as far as using the phrase "postmodern traumatophilia" (Roth 99) to refer to what they see as a political culture 
"saturated with talk of victimization, trauma and shame" (Roth xxii). If the testimonial aspect of photography-in relation to trauma particularly, but not only-derives from its "indexicality" and "evidentiality", two notions emphasized by Roland Barthes and Susan Sontag in their seminal essays Camera Lucida and On Photography (one has in mind Barthes's famous "ça-a-été", "that-has-been"), the two critics have also highlighted the intimate connection between photography and trauma by focusing on their mutual relation to death: if trauma has to do with one's having somehow faced death and survived, the photographic act is, for its part, seen as an "embalming" (Barthes 14) through which the subject becomes reified and disincarnated in a "micro-experience of death" (Barthes 14). Likewise, Susan Sontag views photographic images as "death masks" (Sontag 168) and "memento mori" (Sontag 26). By emphasizing the conjunction of past and present, presence and absence, life and death-be it only metaphoricallyphotography thus figures loss as its arch signifier and induces melancholy. This is even more acute with photographs of traumatic history, and particularly Holocaust photographs, in front of which, as Petra Rau explains, "we respond to what the pictures do not show" (Rau 310). This "blind spot" of photography (Rau 298) is what she calls "the spectral punctum" (Rau 298), after Barthes's famous distinction between punctum and studium. This process recalls what Ulrich Baer in Spectral Evidence describes as photography's capacity "to provide special access to experiences that have remained unremembered yet cannot be forgotten" (Baer 7). For Baer, this capacity that photography has of capturing "unexperienced events" is precisely what connects it so closely to trauma, the "workings of the camera" being strikingly similar to the "structure of traumatic memory" (Baer 8):

Because trauma block routine mental processes from converting an experience into memory or forgetting, it parallels the defining structure of photography, which also traps an event during its occurrence while blocking its transformation into memory. (Baer 8)

Trauma, just like photography, is therefore an "enigma", a "crisis in representational models" (Baer 10), as he puts it, echoing what Cathy Caruth in Unclaimed Experience (1996) calls a "crisis in representation, of history and truth, and of narrative time" (Luckhurst 2008, 5). As Luckhurst explains, this representational impossibility of trauma-described by Caruth by the concept of "aporia" or "unresolvable paradox" (Luckhurst 2008, 4)-in turn generates the paradox of trauma theory which "at once demands representation and insists on the erasures of that ghastly presumption" (Luckhurst 2016, 26). Luckhurst sees this process as applying particularly to Holocaust photography where "direct photographic representation" is disparaged for fear of aestheticizing pain and desensitizing one to horror (Sontag's position in Regarding the Pain of Others), to the benefit of what he calls "anti-representational abstraction or voids" (Luckhurst 2016, 27). To him, this paradox is at the root of what he sees as the "iconoclasm" and "anti-historicism" (Luckhurst 2016, 28) of "poststructuralist theorization of trauma in the 1990s", to use Buelens, Durrant, and Eaglestone's phrase in their recent book The Future of Trauma Theory (2014, xxii).

16 This ethical questioning regarding the "aestheticization of violence" (Luckhurst 2016, 34 ) and "melancholic replay" of trauma (Hirsch 2008, 8) inducing "passivity or contentment" (Reinhardt, quoted by Luckhurst 2016, 28) is particularly manifest in two collections: Reinhardt, Edwards, and Duganne's Beautiful Suffering: Photography and the Traffic in Pain (2007); and Batchen, Gidley, Miller, and Prosser's Picturing Atrocity: Photography in Crisis (2012), which question and complicate Sontag's stance on violence, 
shame, and shock. Rather than inducing a "negative epiphany" (Sontag quoted by Hirsch 4), as well as a passive "desensitization to horror" (Hirsch 2001, 6), photography, with its capacity to produce trauma in the viewer, as well as its privileged status as a "medium" (Hirsch 2001, 13) or "agent" (Hirsch 1997, 248) of "postmemory"-"the response of the second generation to the trauma of the first" (Hirsch 2001, 8)-can mediate familial and collective memory, enable mourning and working through, and therefore act as an "anchor[s] of agency and responsibility" (Hirsch 1997, 164). As postmemorial subjects haunted not just by the spectre of the Holocaust and other, more recent wars, genocides, and terrorist attacks, but also by "industrial exploitation" and "ecological devastation"-the new "geographical or geocultural" directions of trauma examined by Buelens, Durrant, and Eaglestone in their recent book The Future of Trauma Theory-we can, as Hirsch suggests, "engage in an ethical relation to the oppressed" (Hirsch 2001, 10). Thanks to "vicarious traumatization" (Guignery 20), i.e. memory's capacity to "produc[e] rather than scree[n] trauma" (Hirsch 2001, 8), there may be ways to surmount the "frustrating limitations" of photographs (Hirsch 2001, 14), to "redeploy" "the effects of traumatic repetition" and to achieve or, at the very least, move towards "postmemorial working through" (Hirsch 2001, 29) and healing.

\section{Our special issue}

The nine articles presented in this 2018 issue address the question of photography and trauma in relation to testimony, postmemory, healing, and ethical responsibility in a global postwar world where, over the years, new photographic images of trauma have emerged to complicate our sense of those "tropes for Holocaust memory itself", as well as "tropes for photography", that Holocaust photographs have come to represent (Hirsch 2001, 16). Written by scholars from both sides of the Atlantic specializing in trauma theory, theory of photography, text and image, and film theory, these articles discuss photographs and stilled images of, or related to, the traumas of World War II (Petit), Hiroshima (Hays), the Algerian War (Montier), the 1960s Civil Rights (Abel), the Vietnam War (Leblanc), the Rwandan genocide (Morel), 9/11 (Pozorski), and Abu Ghraib (Kalaidjian). They also address scrapbooked personal photographs as they relate to individual trauma (Pedri). Three of these articles (Abel, Kalaidjian, and Pozorski) were previously published and have been reprinted with special permission from the publishers. Let them be thanked here. The other six are new.

Despite the abundance of critical theory on photography since the seminal work of Barthes and Sontag in the 1980s, and on trauma since Cathy Caruth's groundbreaking work in the 1990s; and considering trauma theory's boom in popularity in the 1990s until the late 2000s, as well as the new directions it has taken in recent years, it seems crucial to reconsider the links between photography and trauma in the light of the traumatic events, both old and new, that have had considerable impact on people globally. As the reflections above have shown, these preoccupations have mainly been ethical: what it means to try to represent the unrepresentable, what responsibility and duty such an act entails, particularly in relation to memory and testimony, and what form of healing it can bring to the individual or the community.

The articles as they appear in this issue fall under four sections: the first section examines the manifestations of photography and trauma in their personal (Pedri) or collective (Abel) aspect, as well as their endless repetition and cyclicality (Petit). The 
second section concentrates on the question of witnessing in relation to micro- (the self) and macro- (the community) history (Leblanc), but also in terms of temporality, with the paradoxical notion of "impending trauma" (Pozorski). The third section examines the limits of photography and stilled images when it comes to dealing with trauma either in terms of aporia (Hays) or when it ends up promoting a shocking and counterproductive "glamour of horror" (Morel). The last section suggests ways out of trauma through art (Kalaidjian) so as to "stitch the wounds of the past" and provide "healing" (Montier).

\section{Conclusion: our academic commitment}

In 1992, Dori Laub saw a special case in the five-year-old boy who grew up to survive the Holocaust and to become a brave member and high-ranking officer in the Israeli Army-a man who survived through a creative act but who was also potentially undone by the harsh differences he saw between the photograph of his mother he clutched in his hands and the devastated woman who returned to him after the war. More than 25 years ago, Laub, along with Felman, wondered about the possibility for testimony in an age of trauma, and, in the case of Menachem, understood how his survival depended on three things: a shawl, a photograph, and a promise. In this special issue, we hope to offer a new way to understand photography in relation to traumatic history, and, there, too, offer a kind of promise: an attempt to make academic writing testify when such institutions as the judicial system, journalism, healthcare, government, and politics seem otherwise to fail in accounting for human suffering.

\section{BIBLIOGRAPHY}

Amfreville, Marc. Écrits en souffrance: Figures du trauma dans la littérature nord-américaine. Paris: Michel Houdiard, 2009.

Baer, Ulrich. Spectral Evidence: The Photography of Trauma. Cambridge, MA, and London: MIT, 2002.

Barthes, Roland. La Chambre Claire: notes sur la photographie (1980). Translated as Camera Lucida: Reflections on Photography by Richard Howard. New York: Hill \& Wang, Noondy Press, 1981.

Batchen, Geoffrey, Mick Gidley, Nancy K. Miller, and Jay Prosser (eds.). Picturing Atrocity: Photography in Crisis. London: Reaktion Books, 2012.

Buelens, Gert, Sam Durrant, and Robert Eaglestone (eds.). The Future of Trauma Theory: Contemporary Literary and Cultural Criticism. Oxon: Routledge, 2014.

Caruth, Cathy. Literature in the Ashes of History. Baltimore: Johns Hopkins UP, 2013.

Caruth, Cathy. Unclaimed Experience: Trauma, Narrative, and History. Baltimore: Johns Hopkins UP, 1996.

Charon, Rita. Narrative Medicine: Honoring the Stories of Illness. Oxford: Oxford UP, 2006. 
Felman, Shoshan and Dori Laub. Testimony: Crises of Witnessing in Literature, Psychoanalysis, and History. New York: Routledge, 1992.

Ganteau, Jean-Michel and Susana Onega (eds.). Trauma and Romance in Contemporary British Literature. London: Routledge, 2013.

Ganteau, Jean-Michel and Susana Onega (eds.). Ethics and Trauma in Contemporary British Literature. Amsterdam: Rodopi, 2011.

Guignery, Vanessa. "Photography, Trauma and the Politics of War in Beryl Bainbridge's Master Georgie". Neo-Victorian Tropes of Trauma: The Politics of Bearing After-Witness to Nineteenth-Century Suffering. Marie-Luise Kohlke and Christian Gutleben (eds.). Amsterdam, Netherlands: Rodopi, 2010.

Hirsch, Marianne. "Surviving Images: Holocaust Images and the Work of Postmemory". The Yale Journal of Criticism 14.1 (Spring 2001): 5-37.

Hirsch, Marianne. Family Frames: Photography, Narrative, and Postmemory. Cambridge, MA, and London: Harvard UP, 1997.

Jacobs, Karen (introduction). "Photography Narrating Trauma”. English Language Notes 44.2 (2006): 229-265.

LaCapra, Dominick. Writing History, Writing Trauma. Baltimore: Johns Hopkins UP, 2001.

Leys, Ruth. Trauma: A Genealogy. Chicago: U of Chicago P, 2000.

Luckhurst, Roger. "Why the Dead have come back? The Instance of Photography". New Formations 89/90 (2016): 109-115.

Luckhurst, Roger. The Trauma Question. Oxon: Routledge, 2008.

Rau, Petra. "Beyond punctum and spectrum: Trauma and Photography in Rachel Seiffert's The Dark Room". Journal of European Studies 36.3 (2006): 295-325.

Reinhardt, Mark, Holly Edwards, and Erina Duganne (eds.). Beautiful Suffering: Photography and the Traffic in Pain. Williamstown, MA: Williams College Museum of Art/Chicago: U of Chicago P, 2007.

Roth, Michael S. Memory, Trauma, and History: Essays on Living with the Past. New York: Columbia UP, 2011.

Sontag, Susan. Regarding the Pain of Others. New York: Farrar, Strauss and Giroux, 2003.

Yusin, Jennifer. The Future Life of Trauma: Partitions, Borders, Repetition. New York: Fordam UP, 2017. 